\title{
Aggregation in Azospirillum brasilense: effects of chemical and physical factors and involvement of extracellular components
}

\author{
Saul Burdman, ${ }^{1}$ Edouard Jurkevitch, ${ }^{1}$ Boris Schwartsburd, ${ }^{2}$ \\ Michal Hampel ${ }^{1}$ and Yaacov Okon ${ }^{1}$ \\ Author for correspondence: Yaacov Okon. Tel: +972 89481216 . Fax: +972 89466794. \\ e-mail: okon@agri.huji.ac.il
}

\section{Department of Plant} Pathology and Microbiology, and The Otto Warburg Center for Agricultural

Biotechnology, ${ }^{1}$ and Department of Animal Sciences, ${ }^{2}$ Faculty of Agricultural, Food and Environmental Quality Sciences, The Hebrew University of Jerusalem, Rehovot 76100, Israel

\begin{abstract}
A medium for consistent induction of aggregation of Azospirillum brasilense cells was developed and used to study the effects of chemical and physical factors as well as extracellular components involved in this phenomenon. Growth of A. brasilense strain $\mathrm{Cd}$ in a high $\mathrm{C}: \mathrm{N}$ medium using fructose and ammonium chloride as $\mathrm{C}$ and $\mathrm{N}$ sources, respectively, resulted in flocculation visible to the naked eye after $24 \mathrm{~h}$. No cell aggregates were formed after $72 \mathrm{~h}$ growth in low C: $\mathbf{N}$ medium. Aggregating cells, but not cells grown under low $C: N$, accumulated high amounts of poly- $\beta$-hydroxybutyrate and the cell envelope contained a well-defined electron-dense layer outside the outer membrane. Suspending the aggregates in 0.2 or $0.5 \mathrm{M}$ urea was the only treatment effective for disrupting aggregates. The concentration of exopolysaccharide produced by four different strains of A. brasilense, differing in their capacity to aggregate, strongly correlated with the extent of aggregation. Electrophoretic protein profiles from different fractions of aggregating and non-aggregating cells were compared. Differences were observed in the pattern of low-molecular-mass proteins and in the polar flagellin that has previously been proposed to be involved in adhesion processes. However, a mutant lacking both lateral and polar flagella showed the strongest aggregation. The involvement of polysaccharides and/or proteins in aggregation of A. brasilense is discussed.
\end{abstract}

Keywords: Azospirillum brasilense, aggregation, flocculation, exopolysaccharides

\section{INTRODUCTION}

The free-living $\mathrm{N}_{2}$-fixing rhizobacteria of the genus Azospirillum live in close association with plant roots, where they exert beneficial effects on plant growth and yield of many crops of agronomic importance (Okon \& Labandera-Gonzalez, 1994).

Cell aggregation is a widespread phenomenon in the microbial world. It can be defined as the gathering of cells to form fairly stable, contiguous, multicellular associations, occurring under certain physiological conditions (Calleja, 1984). Free-living $\mathrm{N}_{2}$-fixing bacteria such as Azospirillum, Klebsiella and Azotobacter are known for their capacity to aggregate and flocculate; this property may positively affect their dispersal and

Abbreviations: EPS, exopolysaccharide; PHB, poly- $\beta$-hydroxybutyrate; SEM, scanning electron microscopy; TEM, transmission electron microscopy survival in soil (Nur et al., 1981; Sadasivan \& Neyra, 1985; Madi et al., 1988; Madi \& Henis, 1989). Along with the fact that flocs can be produced on a large scale and separated easily from the growth medium, the phenomenon of bacterial aggregation is of great interest in the production of bacterial inoculants. Neyra $e t$ al. (1995) proposed the generation of inoculants containing flocs of Azospirillum and Rhizobium for common bean plants.

The bacterial surface plays an important role in the establishment of bacterial-plant associations as well as in bacterial aggregation (De Troch \& Vanderleyden, 1996). Data suggesting the involvement of extracellular polysaccharides in Azospirillum aggregation have been published. The production of surface polysaccharides by Azospirillum has been demonstrated by growing colonies on media containing the fluorescent dye calcofluor, which binds predominantly to $1,4-\beta$ and $1,3-\beta$ 
linked glucans (Wood \& Fulcher, 1978). Michiels et al. $(1990,1991)$ showed that non-fluorescent mutants have lost the ability to form flocs and to anchor to wheat roots, indicating that the calcofluor-binding polysaccharide may be necessary for flocculation and anchoring to roots. Sadasivan \& Neyra (1985) related floc formation in A. brasilense Sp7 and A. lipoferum to $\beta$ linked exopolysaccharides. It has recently been found that a spontaneous mutant of $\mathrm{Sp} 7$, which forms colonies that stain weakly with Congo Red, does not flocculate and lacks cell-surface materials found in the parental strain (Katupitiya et al., 1995).

Electron microscopy studies on aggregation of Azospirillum revealed the presence of an extracellular layer (Madi et al., 1988). Treatment of cells with EDTA resulted in the dispersal of aggregates, and addition of the dialysed EDTA extract to the treated bacterial cells restored their aggregation capacity. This evidence indicates the possibility of the involvement of proteins in this phenomenon (Madi \& Henis, 1989). Direct evidence for the involvement of extracellular proteins in the adhesion process of Azospirillum to abiotic surfaces has been provided (Dufrêne et al., 1996a, b; Dufrêne \& Rouxhet, 1996). Extracellular proteins were suggested or demonstrated to directly participate in aggregation of various bacterial species from diverse environments (Eggset et al., 1983; Calleja, 1984; Reniero et al., 1992; Wang et al., 1994; Marsh \& Bradshaw, 1995; Ma et al., 1996; Wai et al., 1996).

Azospirillum cells are able to aggregate, leading to the formation of visible flocs under diverse stress conditions (Bashan \& Holguin, 1997). Following transfer from a rich medium to a N-limited medium (low and high $\mathrm{C}: \mathrm{N}$, respectively), a switch from a dispersive growth pattern to a mode of increased aggregation, clumping and flocculation occurs. A protocol including repeatable and measurable values of aggregate formation and aggregation intensity, respectively, was developed. This system was used to study the nature of the molecular interactions that occur between aggregating cells. In this work, we studied the effects of various chemical and physical factors on the stability of aggregates, and focused on the differential aggregation capacity of various strains of $A$. brasilense to systematically compare biochemical fractions in the search for the 'aggregation principle'.

\section{METHODS}

Bacterial strains and growth conditions. Azospirillum brasilense wild-type strains Cd (Eskew et al., 1977) and Sp7 (Tarrand et al., 1978), and mutant strains FAJ0204 (a Tn5 mutant of Sp7 defective in the production of both lateral and polar flagella; kindly supplied by J. Vanderleyden, Catholic University of Leuven, Belgium) and Sp72002 (a pleiotrophic Tn 5 mutant of Sp7 affected in its aggregation capacity; kindly supplied by C. Elmerich, Institut Pasteur, Paris, France) were maintained on nutrient agar (Difco) slants. Kanamycin was added at $50 \mu \mathrm{g} \mathrm{ml}^{-1}$ for the Tn5 mutant strains. For aggregation assays and extracellular material extraction, bacteria were grown in $250 \mathrm{ml}$ Erlenmeyer flasks, in $100 \mathrm{ml}$ liquid medium. Aggregation-inducing medium (high $\mathrm{C}: \mathrm{N}$ ) contained $\left(\mathrm{g} \mathrm{l}^{-1}\right)$ D-fructose (6.67), $\mathrm{MgSO}_{4}(0 \cdot 2), \mathrm{NaCl}(0 \cdot 1), \mathrm{CaCl}_{2}(0.02)$, $\mathrm{K}_{2} \mathrm{HPO}_{4}(6 \cdot 0), \mathrm{KH}_{2} \mathrm{PO}_{4}(4 \cdot 0)$, yeast extract (Difco) $(0 \cdot 1)$, $\mathrm{NH}_{4} \mathrm{Cl}(0 \cdot 214)$ and microelements as described by Okon et al. (1977). Low C:N medium contained the same components, but with $\mathrm{NH}_{4} \mathrm{Cl}$ at $0.963 \mathrm{~g}^{-1}$. Liquid media were adjusted to $\mathrm{pH}$ 6.8. Flasks were inoculated with exponential-phase cultures to an initial $\mathrm{OD}_{540}$ of approximately 0.05 (about $10^{7}$ c.f.u. $\left.\mathrm{ml}^{-1}\right)$ and incubated on a rotary shaker $(150$ r.p.m.) at $30^{\circ} \mathrm{C}$.

Scanning electron microscopy (SEM). A. brasilense Cd cells were washed by centrifugation $(4000 \mathrm{~g}, 10 \mathrm{~min}$, twice), resuspended in $10 \mathrm{mM}$ phosphate buffer ( $\mathrm{pH} 7 \cdot 2$ ), fixed in $2 \%$ (v/v) glutaraldehyde for $3 \mathrm{~h}$, dehydrated through a graded ethanol series and critical-point dried. Dried bacteria were coated with gold by a diode sputtering system (Polaron E5000) and observed with a JEOL JSM-35C scanning electron microscope.

Transmission electron microscopy (TEM). Bacteria were washed by centrifugation $(4000 \mathrm{~g}, 10 \mathrm{~min}$, twice), resuspended in $10 \mathrm{mM}$ phosphate buffer ( $\mathrm{pH} 7 \cdot 2)$, fixed in $3 \%(\mathrm{v} / \mathrm{v})$ glutaraldehyde for $3 \mathrm{~h}$, postixed in $1 \%(\mathrm{w} / \mathrm{v}) \mathrm{OsO}_{4}$ for $2 \mathrm{~h}$ and rinsed three times in $50 \mathrm{mM}$ sodium cacodylate buffer ( $\mathrm{pH} 7 \cdot 2$ ). Rinsed bacteria were then dehydrated through a graded ethanol series and embedded in a low-viscosity epoxy resin. Samples were dried at $60^{\circ} \mathrm{C}$ for $24 \mathrm{~h}$. Thin sections were cut with a diamond knife on an 8800 ultramicrotome (LKB), stained with uranyl acetate and lead citrate, and examined on a JEOL 100-CX transmission electron microscope.

Quantitative measurement of aggregation. The extent of aggregation was measured during growth or following different treatments according to Madi \& Henis (1989), with some modifications. Aliquots of liquid culture containing aggregates were transferred to a conical tube and allowed to stand. After $20 \mathrm{~min}$, aggregates had settled to the bottom of the tube and the suspension was mostly composed of free cells. Turbidity was measured from the suspension using a Genesis 5 spectrophotometer (Spectronic Instruments) at $540 \mathrm{~nm}$ $\left(\mathrm{OD}_{\mathrm{s}}\right)$. The culture was then dispersed by treatment in a tissue homogenizer (Heidolph RzR 50) for $1 \mathrm{~min}$ and the total turbidity was measured $\left(O D_{t}\right)$. The percentage aggregation was estimated as follows: \% aggregation $=\left[\left(\mathrm{OD}_{\mathrm{t}}-\mathrm{OD}_{\mathrm{s}}\right) \times\right.$ $100] / \mathrm{OD}_{\mathrm{t}}$.

Effects of chemicals and pH on the stability of aggregates. Bacteria were grown for $24 \mathrm{~h}$ in a high C: $\mathrm{N}$ medium, washed by centrifugation $(4000 \mathrm{~g}, 10 \mathrm{~min}$, twice) and resuspended in a saline solution $(0.9 \%, \mathrm{w} / \mathrm{v}, \mathrm{NaCl})$. Aggregates were dispersed by homogenization and bacteria were transferred to $10 \mathrm{vols}$ treatment solution. Chemical treatments were applied at different concentrations in $10 \mathrm{mM}$ phosphate buffer $(\mathrm{pH} 7 \cdot 0)$. For $\mathrm{pH}$ experiments, washed bacteria were resuspended in citrate/phosphate buffer $\left(0.1 \mathrm{M}\right.$ citric acid, $0.2 \mathrm{M} \mathrm{Na}_{2} \mathrm{HPO}_{4}$, $\mathrm{pH} 3-7$ ) or in $0.1 \mathrm{M} \mathrm{Tris} / \mathrm{HCl}$ buffer $(\mathrm{pH} 8$ and 9). The extent of aggregation was measured as described above, after shaking for $30 \mathrm{~min}\left(150 \mathrm{r}\right.$.p.m., $\left.30^{\circ} \mathrm{C}\right)$ at the various selected pH levels or at different times of incubation for the chemical treatments.

Isolation of proteins from different fractions. Proteins were isolated from different fractions of bacteria grown for $24 \mathrm{~h}$, to compare protein profiles between strains and between the two types of media (low and high C:N). Bacteria were pelleted by centrifugation $(4000 \mathrm{~g}, 20 \mathrm{~min})$. The two fractions tested were the supernatant (growth medium) and the pelleted bacteria. To remove proteins associated with the cell surface, the pellet was resuspended in $5 \mathrm{ml}$ water and passed five times through a $25 \mathrm{G} \times 5 / 8$ inch needle or sonicated for $20 \mathrm{~s}$, then recentri- 
fuged $(4000 \mathrm{~g}, 20 \mathrm{~min})$. Outer-membrane proteins were extracted according to Schloter et al. (1994). All fractions were filtered through a $0.22 \mu \mathrm{m}$ membrane and dialysed against distilled water for $24 \mathrm{~h}$ at $4{ }^{\circ} \mathrm{C}$, using a dialysis membrane with a molecular-mass cut-off of $10 \mathrm{kDa}$.

Gel electrophoresis. Proteins were separated by electrophoresis in SDS-polyacrylamide gels $(12 \%, \mathrm{w} / \mathrm{v}$, acrylamide) and stained with Coomassie brilliant blue G250, using standard methods (Hancock \& Carey, 1979). The molecular masses of the proteins were estimated using low-range prestained standards (Bio-Rad). Glycoproteins were detected using Schiff's reagent (Sigma).

Western blotting. Gels were electroblotted onto Immobilon-P membranes (Millipore). Immunodetection of the polar $\mathrm{fla}$ gellin was achieved with AS-Fla1, an antiserum against the polar flagellum of A. brasilense (Croes et al., 1993), a gift of J. Vanderleyden (Catholic University of Leuven, Belgium). Horseradish-peroxidase conjugated anti-rabbit IgG (Bio Makor) secondary antiserum was used with 4-chloro-1naphthol as a substrate to develop the blots (Harlow \& Lane, 1988).

Quantification of polysaccharides and proteins from growth medium. Exopolysaccharides (EPSs) were quantified by a method described by Del Gallo \& Haegi (1990) with some modifications. Bacteria grown for $24 \mathrm{~h}$ were removed by centrifugation $(4000 \mathrm{~g}, 20 \mathrm{~min})$. The supernatant was then filtered through a $0.22 \mu \mathrm{m}$ membrane. Ethanol-insoluble EPS was precipitated overnight at $4{ }^{\circ} \mathrm{C}$ with 3 vols cold ethanol. After centrifugation $(30000 \mathrm{~g}, 20 \mathrm{~min})$, the EPS was resuspended in and dialysed against distilled water for $3 \mathrm{~d}$ at $4{ }^{\circ} \mathrm{C}$, using a dialysis membrane with a $2 \mathrm{kDa}$ molecular mass cut-off. The amounts of sugar in the polysaccharide fractions were determined by the anthrone method, using glucose as a standard (Dische, 1962). The amounts of protein in dialysed growth medium were determined by the method of Bradford (1976), using BSA as the standard.

All experiments were carried out at least three times and were highly reproducibile. Therefore, data from one of each experiment are presented.

\section{RESULTS AND DISCUSSION}

\section{Microscopic studies on aggregation of $A$. brasilense $\mathrm{Cd}$ in high $\mathrm{C}: \mathrm{N}$ medium}

Relatively high $\mathrm{C}: \mathrm{N}$ ratios may induce aggregation of A. brasilense cells in liquid media (Madi \& Henis, 1989; Arunakumari et al., 1992). However, the use of organic acids as carbon sources alters the $\mathrm{pH}$ of the medium during the course of growth (Madi \& Henis, 1989), and aggregation is not always consistent. To study chemical, physical and extracellular factors involved in the aggregation process, a medium consistently yielding aggregates was developed. Cells of $A$. brasilense strain $\mathrm{Cd}$ growing on fructose $(37 \mathrm{mM})$ as the sole $C$ source with $4 \mathrm{mM} \mathrm{NH}_{4} \mathrm{Cl}$ (high $\mathrm{C}: \mathrm{N}$ ) aggregated, yielding cell flocs visible after $24 \mathrm{~h}$. In a fructose medium containing $18 \mathrm{mM} \mathrm{NH}_{4} \mathrm{Cl}$ (low $\mathrm{C}: \mathrm{N}$ ), no aggregates of this strain were formed even after $72 \mathrm{~h}$ of growth.

A similar pattern of aggregation with high $C: N$ as compared with low $\mathrm{C}: \mathrm{N}$ was observed using arabinose, galactose and glycerol as $\mathrm{C}$ sources. Use of malate and succinate led to non-reproducible results, probably due to the observed drastic changes in $\mathrm{pH}$ occurring during growth. It is known that under various stress conditions, bacteria are capable of floc formation, which may improve survival (Bashan \& Holguin, 1997).

Aggregated and non-aggregated cultures differed greatly in their morphological features, as revealed by SEM and TEM (Fig. 1). Under aggregation-inducing conditions, cells grown for $24 \mathrm{~h}$ appeared to be connected by fibrillar bridges (Fig. 1a, c) that were not observed at the low $\mathrm{C}: \mathrm{N}$ ratio (Fig. $1 \mathrm{~b}, \mathrm{~d}$ ). Natural components produced by micro-organisms as extracellular products can function as bridging polymers (Harris \& Mitchell, 1973) and many floc-forming bacteria have been shown to produce extracellular fibrils that are efficient in polymer bridging; such fibrils are of a cellulosic nature in many species (Marshall, 1976). Del Gallo et al. (1989) suggested the involvement of a cellulosic polysaccharide in aggregation of Azospirillum; however, no cellulose fibrils were detected in $A$. brasilense strain Cd by Madi \& Henis (1989).

Aggregating cells accumulated high amounts of poly- $\beta$ hydroxybutyrate (PHB) in granules (Fig. 1e, g) and the cell envelope contained a well-defined electron-dense layer above the outer membrane (Fig. 1g, i). In nonaggregating cells, no PHB was seen after $24 \mathrm{~h}$ and the cell envelope appeared to be diffuse and less well defined (Fig. 1f, h, j). These results are similar to those of Madi et al. (1988), which revealed the presence of an extracellular layer on the outer surface of aggregating cells grown in a malate synthetic medium. PHB accumulation and the formation of a thick layer of EPSs were also observed during flocculation and encystation of $A$. brasilense Sp7 by Sadasivan \& Neyra (1985).

\section{Quantitative measurement of aggregation of various A. brasilense strains}

Strain $\mathrm{Sp} 7$ aggregated almost three times as much as strain Cd under high C: $\mathrm{N}$ conditions (Table 1). Sp72002, a pleiotropic $\operatorname{Tn} 5$ mutant, did not aggregate even after $72 \mathrm{~h}$. The other mutant, FA J0204, which lacks both lateral and polar flagella, is a superaggregating strain, reaching more than $70 \%$ aggregation after $72 \mathrm{~h}$. Strains FA J0204 and Sp7 also aggregated in low C:N, but to a much lower extent than in high $\mathrm{C}: \mathrm{N}$ medium (Table 1 ).

Aggregate formation started within a few hours of growth in high C: $\mathrm{N}$ medium, except for strain Sp72002. It was necessary to differentiate between micro- and macro-aggregates (flocs). The micro-aggregates consist of relatively small clumps of cells that were only visible under the microscope (Fig. 2a); they were formed in the early exponential phase, causing the observed rapid increase in percentage of aggregation. The macroaggregates consisted of large aggregates and were visible to the naked eye (Fig. 2b). Flocs were observed during the early to mid-exponential phase of growth in strains Sp7 and FAJ0204, but only towards the end of the exponential phase in strain $\mathrm{Cd}$. The appearance of flocs in this strain did not cause a further increase in the percentage of aggregation, which is a relative value: the number and size of aggregates increased along with the 

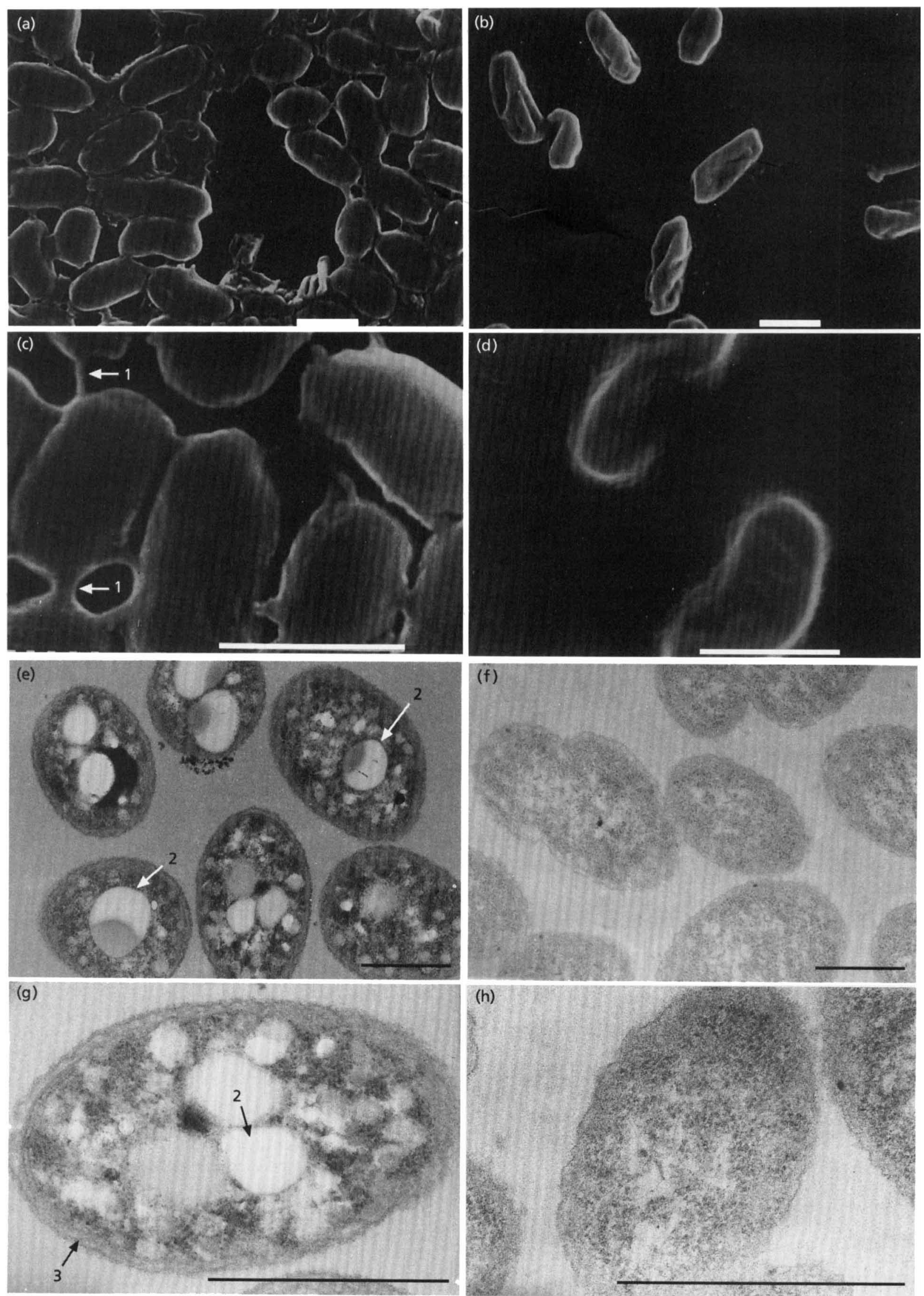

Fig. 1 (a)-(h). For legend see facing page. 
Table 1. Growth and aggregation parameters and concentration of EPS and proteins in growth medium for several strains of $A$. brasilense after $24 \mathrm{~h}$ growth under high or low C:N

Each value represents the mean and SE (in parentheses) of three replicates from one representative experiment. Each experiment was carried out three to five times and yielded similar results.

\begin{tabular}{|c|c|c|c|c|c|c|c|c|}
\hline \multirow{2}{*}{$\begin{array}{l}\text { Strain ... } \\
\text { C:N ratio... }\end{array}$} & \multicolumn{2}{|c|}{ FAJ0204 } & \multicolumn{2}{|c|}{ Sp7 } & \multicolumn{2}{|c|}{ Cd } & \multicolumn{2}{|c|}{ Sp72002 } \\
\hline & High & Low & High & Low & High & Low & High & Low \\
\hline Dry weight* & $\begin{array}{c}0.105 \\
(0.007)\end{array}$ & $\begin{array}{c}0.164 \\
(0.006)\end{array}$ & $\begin{array}{c}0.105 \\
(0.003)\end{array}$ & $\begin{array}{c}0.160 \\
(0.005)\end{array}$ & $\begin{array}{c}0.100 \\
(0.005)\end{array}$ & $\begin{array}{c}0 \cdot 162 \\
(0 \cdot 010)\end{array}$ & $\begin{array}{c}0.098 \\
(0.004)\end{array}$ & $\begin{array}{c}0.166 \\
(0.006)\end{array}$ \\
\hline Aggregation (\%) & $\begin{array}{c}58 \cdot 0 \\
(8 \cdot 2)\end{array}$ & $\begin{array}{l}22 \cdot 2 \\
(4 \cdot 2)\end{array}$ & $\begin{array}{c}39 \cdot 2 \\
(4 \cdot 6)\end{array}$ & $\begin{array}{c}6 \cdot 1 \\
(2 \cdot 7)\end{array}$ & $\begin{array}{l}15 \cdot 3 \\
(3 \cdot 0)\end{array}$ & $-\dagger$ & $-t$ & $-t$ \\
\hline EPSł & $\begin{array}{c}7.52 \\
(1.17)\end{array}$ & $\begin{array}{l}11.99 \\
(1.90)\end{array}$ & $\begin{array}{c}4 \cdot 89 \\
(0.46)\end{array}$ & $\begin{array}{c}4.59 \\
(0.99)\end{array}$ & $\begin{array}{c}2 \cdot 76 \\
(0 \cdot 15)\end{array}$ & $\begin{array}{c}4 \cdot 09 \\
(0 \cdot 22)\end{array}$ & $\begin{array}{c}2 \cdot 74 \\
(0 \cdot 31)\end{array}$ & $\begin{array}{c}2 \cdot 12 \\
(0 \cdot 10)\end{array}$ \\
\hline Protein & $\begin{array}{c}1.09 \\
(0.16)\end{array}$ & $\begin{array}{c}4 \cdot 46 \\
(1 \cdot 18)\end{array}$ & $\begin{array}{c}1.89 \\
(0 \cdot 18)\end{array}$ & $\begin{array}{c}3 \cdot 70 \\
(1.73)\end{array}$ & $\begin{array}{c}1 \cdot 10 \\
(0 \cdot 20)\end{array}$ & $\begin{array}{c}4 \cdot 17 \\
(0 \cdot 49)\end{array}$ & $\begin{array}{c}2 \cdot 02 \\
(0 \cdot 12)\end{array}$ & $\begin{array}{c}2 \cdot 70 \\
(1 \cdot 24)\end{array}$ \\
\hline Protein:EPS ratio & $\begin{array}{c}0.14 \\
(0.05)\end{array}$ & $\begin{array}{c}0.37 \\
(0.09)\end{array}$ & $\begin{array}{c}0.39 \\
(0.03)\end{array}$ & $\begin{array}{c}0.81 \\
(0.21)\end{array}$ & $\begin{array}{c}0.40 \\
(0.07)\end{array}$ & $\begin{array}{c}1 \cdot 02 \\
(0 \cdot 12)\end{array}$ & $\begin{array}{c}0.74 \\
(0 \cdot 10)\end{array}$ & $\begin{array}{c}1 \cdot 27 \\
(0 \cdot 49)\end{array}$ \\
\hline
\end{tabular}

*Values are expressed as $\mathrm{g}$ dried bacteria $(100 \mathrm{ml} \text { growth medium })^{-1}$.

† No aggregation was obtained even after $72 \mathrm{~h}$.

¥Values are expressed as mg sugar or protein ( $\mathrm{g}$ dried bacteria) ${ }^{-1}$.

number of free cells in the culture, leading in the case of strain $\mathrm{Cd}$ to a plateau after $12 \mathrm{~h}$ growth. However, the percentage of aggregation continued to increase in strain Sp7 up to late exponential phase. In mutant FAJ0204, a weak increase in aggregation was observed even during the stationary phase.

As expected, under $\mathrm{N}$-limiting conditions, the growth of all tested strains resulted in lower cell yields than growth in low $\mathrm{C}: \mathrm{N}$ medium (Table 1). No differences in growth capacity were observed among strains in each medium, as observed by the similar dry weights obtained (Table 1). Thus, differences in aggregation intensity cannot be related to differences in growth.

Differences in the extent of aggregation among the strains after $24 \mathrm{~h}$ growth are illustrated in Fig. 3. The different behaviour of these strains with respect to aggregation may be a useful tool for the investigation of the aggregation process by providing detectable dif-
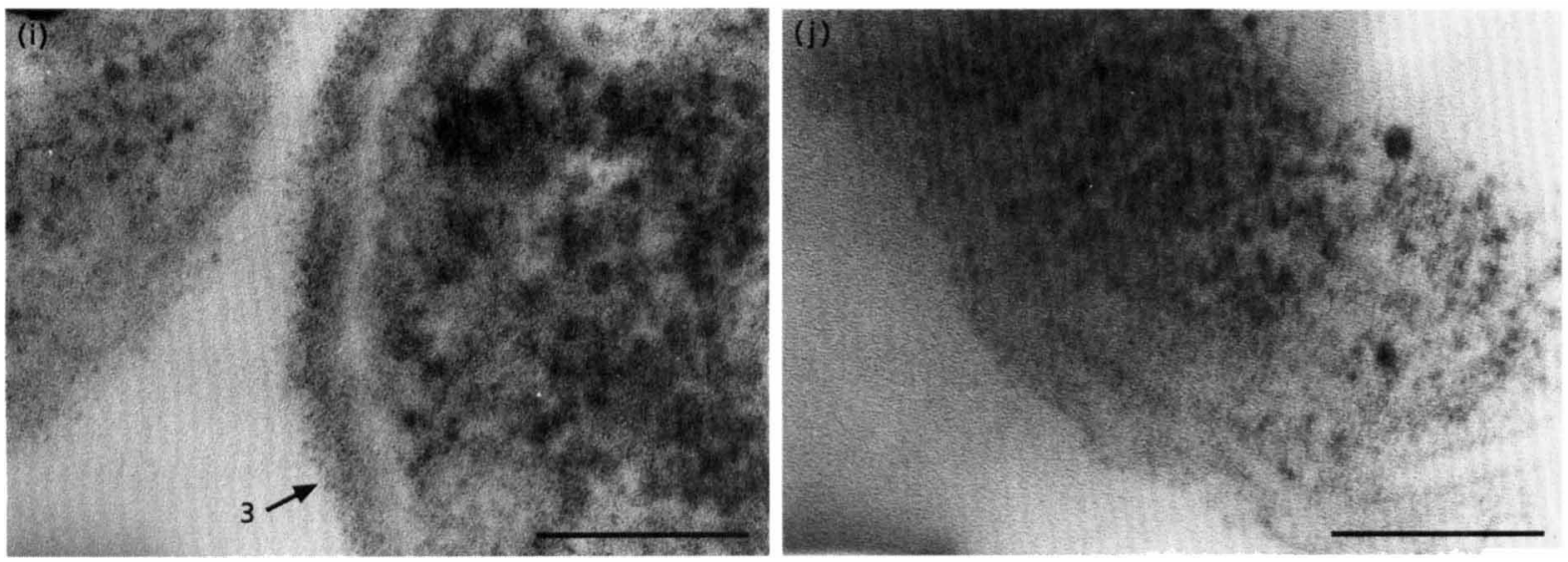

Fig. 1. Scanning electron micrographs of $\mathrm{Cd}$ cells grown for $24 \mathrm{~h}$ in high- (a, c) and low- (b, d) C:N media. Transmission electron micrographs of Cd cells grown for $24 \mathrm{~h}$ in high- $(e, g, i)$ and low- $(f, h, j) C: N$ media. Arrows: 1, fibrillar 'bridges' between cells; 2 , PHB granules; 3, extracellular electron-dense layer. Bars, $1 \mu \mathrm{m}(a-h), 10 \mu \mathrm{m}$ ( $i$ and j). 

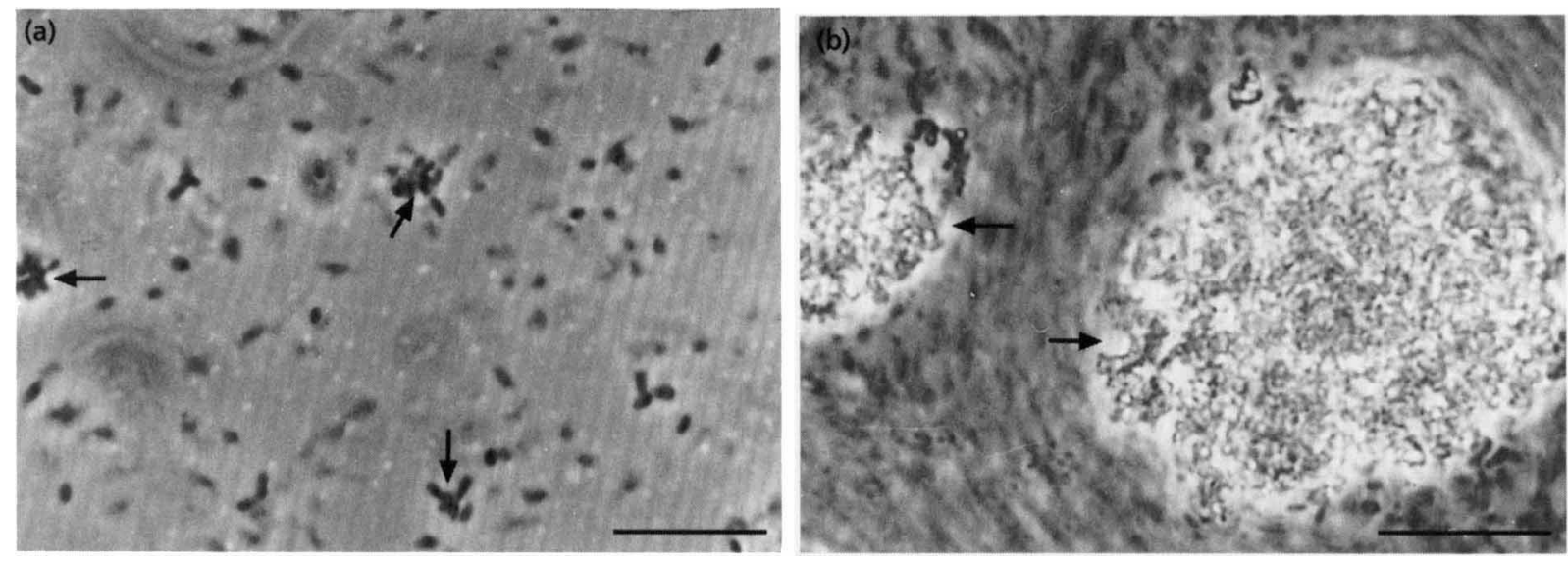

Fig. 2. Light microscopic observation of (a) micro-aggregates and (b) macro-aggregates (flocs) of high-C: $\mathrm{N}-\mathrm{grown} \mathrm{Cd}$ cells. Bars, $1 \mu \mathrm{m}$.

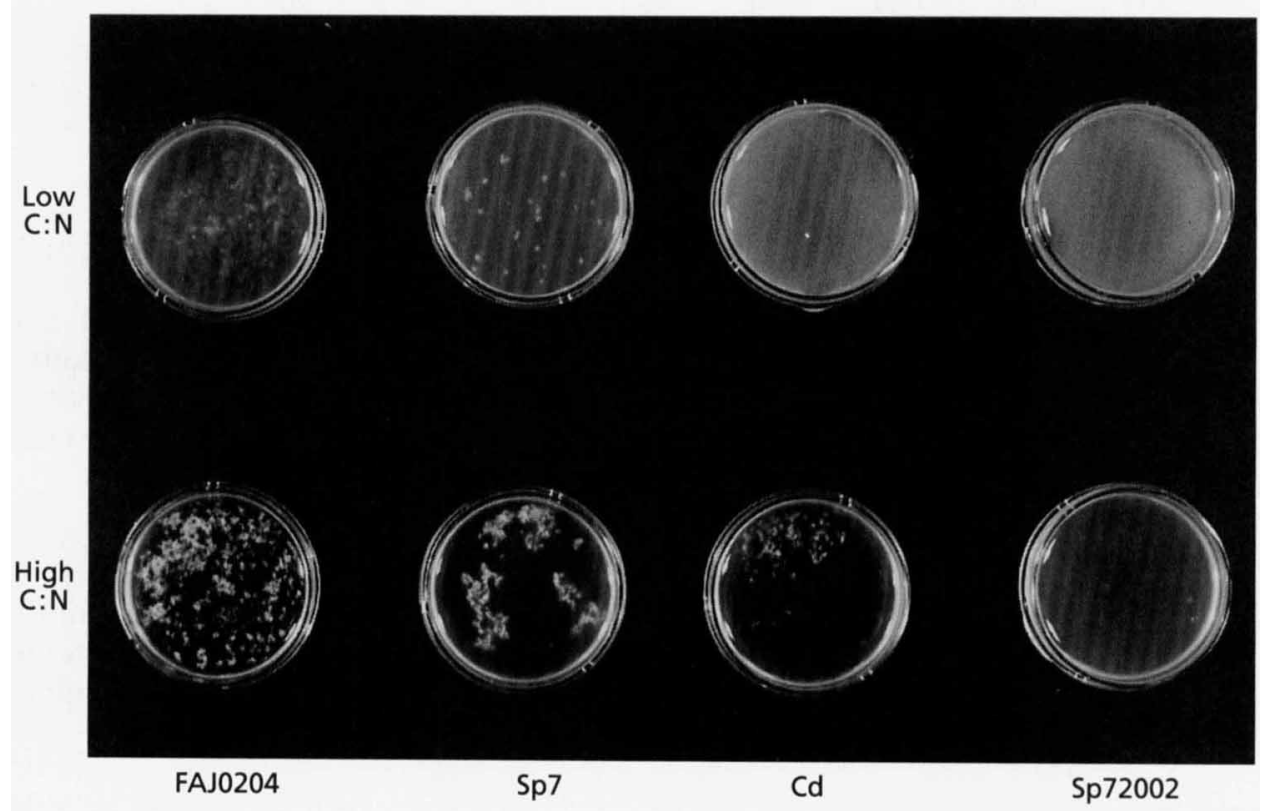

Fig. 3. Aggregation of the four strains after $24 \mathrm{~h}$ growth in low- and high-C:N media. Bacteria were transferred to Petri dishes before the photograph was taken.

ferences in surface components. In a hydrophobicity test using a two-phase water-hydrocarbon partitioning system (according to Arunakumari et al., 1992), all strains were found to be surface-hydrophilic under both high and low $\mathrm{C}: \mathrm{N}$ conditions.

\section{Effects of physical and chemical factors on aggregation of A. brasilense}

Mechanical homogenization caused a momentary disruption of aggregates, which re-formed within a few seconds after the termination of this treatment. A more effective disruption was obtained by sonicating the cells for $20 \mathrm{~s}$ (Table 2), although a small decrease in cell viability was observed, as estimated by observation of bacteria under a microscope and by plating. Prolonged sonication (1,2 and $5 \mathrm{~min}$ ) caused a stronger disruption of aggregates, but concomitantly greatly reduced cell viability. Heat treatment of high-C:N-grown cells $\left(80^{\circ} \mathrm{C}, 20 \mathrm{~min}\right)$ strongly promoted aggregation (Table 2) and an autoclave treatment $\left(121^{\circ} \mathrm{C}, 20 \mathrm{~min}\right)$ of the cell suspension further enhanced the process (data not shown). It is important to note that both the sonication and the heat treatments first caused aggregate dispersion, but aggregates re-formed to a greater extent after incubation than the controls in the heat-treated 
Table 2. Effects of sonication and heat treatment on aggregate stability of $A$. brasilense

Cells were grown for $24 \mathrm{~h}$ in high-C: $\mathrm{N}$ medium, washed by centrifugation $(4000 \mathrm{~g}, 10 \mathrm{~min}$, twice) and resuspended in saline solution. Aggregate-containing suspensions were then sonicated for $20 \mathrm{~s}$ or heated at $80^{\circ} \mathrm{C}$ for $20 \mathrm{~min}$. Controls were untreated suspensions. Percentage aggregation was measured according to the described methodology, after shaking for $30 \mathrm{~min}$

$\left(150\right.$ r.p.m., $30^{\circ} \mathrm{C}$ ). Each value represents the mean of three replicates from one representative experiment. This experiment was carried out three times and yielded similar results.

Different letters within columns indicate significant differences at $P=0.05$ according to one-way analysis of variance.

\begin{tabular}{|llrr|}
\hline Treatment & \multicolumn{3}{c|}{ Percentage aggregation } \\
\cline { 2 - 4 } & FAJ0204 & Sp7 & Cd \\
\hline Control & $29 \cdot 7^{a}$ & $19 \cdot 0^{b}$ & $16 \cdot 6^{b}$ \\
Sonication & $15 \cdot 7^{b}$ & $8.9^{c}$ & $4 \cdot 6^{c}$ \\
Heat treatment & $36 \cdot 2^{a}$ & $37 \cdot 5^{a}$ & $33 \cdot 8^{a}$ \\
\hline
\end{tabular}

cells (Table 2). Physical methods of aggregate dispersion have been found to be reversible in a number of systems, even when causing cell death, as heat does (Calleja, 1984).

The effects of some chemicals, including the proteindenaturing agents $\beta$-mercaptoethanol, urea and SDS, and the chelators EDTA and EGTA, on aggregation of $A$. brasilense $\mathrm{Cd}$ were tested. Aggregate dispersion caused by some of these chemical treatments may point to the involvement of proteins in cell-to-cell adhesion. Moreover, it can indicate the nature of the forces implicated in cell cohesion (Calleja, 1984). Treatments with $0.5-2.5 \%(\mathrm{v} / \mathrm{v}) \beta$-mercaptoethanol, 1.0-2.5 M urea, $0.05-0.25 \%(\mathrm{w} / \mathrm{v})$ SDS and $0.5-5.0 \mathrm{mM}$ EDTA were unable to prevent reaggregation of cells after disruption by mechanical homogenization. Higher concentrations of these compounds drastically reduced cell viability and caused partial lysis of bacteria with a few aggregates still visible, except for $0.5 \%(\mathrm{w} / \mathrm{v})$ SDS, in which cell lysis was almost complete. As for untreated controls, treated cells reaggregated immediately after the termination of the disruption; the extent of relative aggregation of treated cells was marginally smaller (varying between approximately 85 and $90 \%$ ) in comparison to controls $(100 \%)$. Re-formed aggregates were very stable and remained intact for several days. After rehomogenization of cells treated for $1 \mathrm{~h}$, aggregates also reformed. EGTA, a more specific $\mathrm{Ca}^{2+}$ chelator, also failed to prevent reaggregation.

Low concentrations of urea $(0.2$ and $0.5 \mathrm{M})$ led to efficient disruption of aggregates without apparent loss of viability. Similar to the other treatments, reaggregation occurred immediately after homogenization of the tested suspension. However, in $0.2 \mathrm{M}$ urea, the aggregates were completely disrupted after $4 \mathrm{~h}$ of incubation, during which homogenization was per-
Table 3. Effects of different concentrations of urea (in $0.1 \mathrm{M}$ phosphate buffer) on aggregate stability of $A$. brasilense strain $\mathrm{Cd}$.

Percentage aggregation was measured according to the described methodology, after shaking for $4 \mathrm{~h}$ (150 r.p.m., $30^{\circ} \mathrm{C}$ ), during which homogenization was either performed every hour or not. Each value represents the mean of three replicates from one representative experiment. This experiment was carried out three times and yielded similar results. Different letters within columns indicate significant differences at $P=0.05$ according to one-way analysis of variance.

\begin{tabular}{|lcc|}
\hline Urea concn $(M)$ & \multicolumn{2}{c|}{ Percentage aggregation } \\
\cline { 2 - 3 } & $\begin{array}{c}\text { With } \\
\text { homogenization }\end{array}$ & $\begin{array}{c}\text { Without } \\
\text { homogenization }\end{array}$ \\
\hline 0 (control) & $11 \cdot 6^{a}$ & $15 \cdot 0^{a}$ \\
$0 \cdot 2$ & $0 \cdot 0^{b}$ & $6 \cdot 8^{c}$ \\
$0 \cdot 5$ & $6 \cdot 6^{a}$ & $10 \cdot 1^{b}$ \\
1.0 & $11 \cdot 0^{a}$ & $11 \cdot 7^{a b}$ \\
2.5 & $11 \cdot 3^{a}$ & $12 \cdot 4^{a b}$ \\
\hline
\end{tabular}

formed every hour (Table 3), without affecting cell viability. Aggregation was reduced in $0.5 \mathrm{M}$ urea within the same time span (Table 3), and complete disruption of aggregates was observed after $6 \mathrm{~h}$ (data not shown). A longer incubation period was needed to achieve aggregate disruption without hourly homogenization (Table 3). High concentrations of urea, like high concentrations of salt, can act as a non-specific aggregating agent. This may explain why aggregate disruption was only achieved at relatively low concentrations of urea.

The results obtained with the various chemicals used suggest that neither disulfide bonds nor divalent cations and hydrophobic interactions play a major role in the aggregation of $A$. brasilense Cd. Disruption of aggregates by relatively low concentrations of urea could be achieved by changes in the conformation of molecular groups directly involved in aggregation. This may indicate that hydrogen bonds are implicated in cell-tocell adhesion. However, it is possible that this treatment disperses aggregates by releasing the functional 'aggregation molecule(s)' from the cell surface. Bacterial suspensions treated with 0.2 or $0.5 \mathrm{M}$ urea, and then washed by centrifugation and dialysis to remove the urea, were unable to reaggregate. This indicates that molecules involved in cell-to-cell interactions leading to aggregation were irreversibly altered, or rinsed from the cell surface.

\section{Effects of pH on the stability of aggregates}

The effects of $\mathrm{pH}$ on aggregation were studied to test the involvement of charged groups in this process. Strains Cd and FA J0204 showed increased reaggregation at the lower $\mathrm{pH}$ levels, with the highest values obtained at 

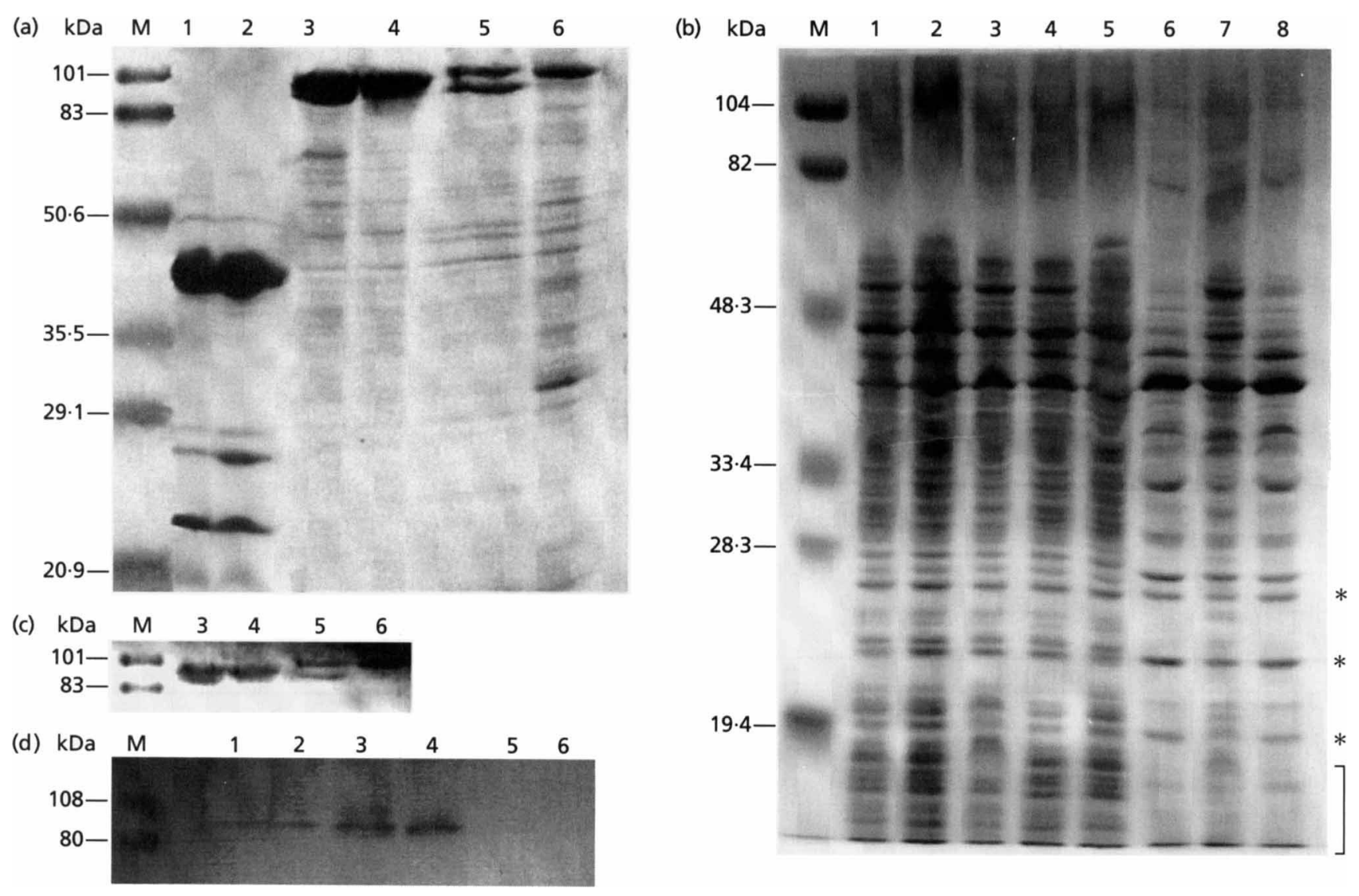

Fig. 4. (a) SDS-PAGE of different fractions of $A$. brasilense Cd cells after $24 \mathrm{~h}$ growth in high- (lanes $1,3,5$ ) or low- (lanes $2,4,6)$ C:N medium. Lanes: $M$, prestained markers; 1,2 , outer-membrane proteins; 3, 4, proteins extracted after passage through a hypodermic needle; 5,6 , proteins extracted from growth media. (b) SDS-PAGE from sonicated fractions of $A$. brasilense cells after $24 \mathrm{~h}$ growth in high- (lanes 1-4) or low- (5-8) C:N medium. Lanes: $\mathrm{M}$, prestained markers; 1, 5, FAJ0204; 2, 6, Sp7; 3, 7, Cd; 4, 8, Sp72002. (c) Reaction of lanes 3 to 6 from (a) with Schiff's reagent. (d) Western blotting of extracts from $A$. brasilense cells grown for $24 \mathrm{~h}$ after passage through a hypodermic needle using AS-Fla 1, an antiserum against the polar flagellum. Lanes: $M$, markers; 1,2 , Sp7; 3, 4, Sp72002; 5, 6, FAJ0204. High-C:N media (lanes $1,3,5)$, low-C:N media (lanes 2, 4, 6). Asterisks and bracket indicate band positions mentioned in the text.

pH 3 (data not shown). A weak tendency of increased reaggregation at alkaline $\mathrm{pH}$ was also observed in these strains. The extent of reaggregation of strain $\mathrm{Sp} 7$, in contrast to strains Cd and FAJ0204, was not affected by $\mathrm{pH}$.

The increase in the extent of reaggregation at acidic $\mathrm{pH}$ levels in strains Cd and FAJ0204 was inversely correlated with aggregate size. The more basic or acidic the $\mathrm{pH}$, the more cell viability was affected. Aggregates at all $\mathrm{pH}$ levels were stable and remained intact for several days. Moreover, aggregates re-formed after various rehomogenization rounds, even when cell viability was lost. These findings may indicate the involvement of charged groups in this phenomenon, at least for strains $\mathrm{Cd}$ and FAJ0204, which showed a differential response to $\mathrm{pH}$. Bacterial cells have predominantly negative charges at physiological pH (Bitton \& Marshall, 1980; Foster \& Bowen, 1982). At acidic $\mathrm{pH}$, negative ionized groups can be neutralized by protonation, thus diminishing the strength of the repulsive forces between bacteria and leading to increased aggregation.

\section{Profile of extracellular proteins of different strains in high- and low-C:N media}

Proteins were extracted from several fractions of $A$. brasilense cells grown in low- or high-C: $\mathrm{N}$ media and their electrophoretic profiles were determined by SDSPAGE. No differences were found in the profiles of outer-membrane proteins (Fig. 4a) from aggregating and non-aggregating $\mathrm{Cd}$ cultures. Both extracts showed high concentrations of the major $42 \mathrm{kDa}$ protein, which has been shown to constitute about $60 \%$ of the total outer-membrane proteins (Bachhawat \& Ghosh, 1987). A clear difference in the intensity of an approximately $100 \mathrm{kDa}$ double band was detected: the lower band of the spent-medium extract of aggregated cells was strong, whereas that of non-aggregating cells was barely visible. Recovery of the double band was more efficient by passing cells through a hypodermic needle than by direct extraction from the medium, and its intensity was stronger in hypodermic-needle extracts from aggregated cultures than from non-aggregating ones (Fig. 4a). These bands react positively with Schiff's reagent (Fig. 4c) and 
may therefore be glycoproteins. The same was found for strains Sp7 and Sp72002, although the double band appeared to be weaker. This band also reacted positively with AS-Fla1, an antiserum against the polar flagellum (Fig. 4d).

Madi \& Henis (1989) suggested that a glycoprotein $(97 \mathrm{kDa})$ located on the outer surface of the cells is involved in the aggregation of Azospirillum cells. Moens et al. (1995) have recently shown that the flagellin of the polar flagellum of Azospirillum consists of a glycoprotein with a similar molecular mass. Moreover, it has been repeatedly observed that two cross-reactive closely spaced bands appear, indicating possible differences in the extent of post-translational modifications (Moens $e t$ al., 1995). According to these data, and since no other bands from extracellular-protein extracts reacted positively with Schiff's reagent, it can be suggested that the putative glycoproteins detected in the two studies cited above and in the present work are the same. It has been shown that the first step in the adhesion of $A$. brasilense to wheat roots is mediated by an adhesin, closely associated with the polar flagellum (Croes et al., 1993). Cells lacking the polar flagellum fail to adsorb to wheat roots, whereas purified polar flagella specifically adsorb onto the root surface.

However, the non-motile mutant strain FAJ0204 aggregates to a greater extent than the wild-type. This mutant does not produce a polar flagellum. Moreover, no band in the protein profiles of this strain reacted positively to Schiff's reagent and none was detected in the Western blot against AS-Fla1 (Fig. 4d), indicating that no peptide reminiscent of such a glycoprotein is produced by this strain.

Proteinaceous adhesins participate in many adherence and attachment processes in which bacteria are involved. In some of these processes, adhesive properties have been attributed to bacterial flagella. This, however, has been postulated rather than proven, with the flagella being only of secondary importance (Moens \& Vanderleyden, 1996). Results from this study cast doubt on the possible involvement of the flagellin of the polar flagellum as a main determinant of aggregation in $A$. brasilense. This is in spite of the observed differences in the electrophoretic pattern of the detected glycoprotein between aggregating and non-aggregating cultures in wild-type strains.

Strain FAJ0204 is one of several Tn5 mutants obtained from wild-type Sp7 which are affected in the production of both lateral and polar flagella. Analysis of the DNA flanking the transposon insertion site revealed a high level of similarity to the fliG gene of Caulobacter crescentus ( $\mathrm{S}$. Moens, personal communication), which encodes a protein involved in the regulation of both the rotation and the biogenesis of the bacterial flagellum (Ramakrishnan et al., 1994). This, along with findings from the present work, indicates that even if the role of the polar flagellum in the aggregation process is not clear, both aggregation and flagellation processes could share one or more regulator genes.
Since aggregates were found to be very stable even when using drastic disruption methods, components directly involved in cell-to-cell adhesion may not be readily extractable. A more thorough treatment was applied by sonicating the cells for $20 \mathrm{~s}$ (Table 2). The supernatant was then analysed. As can be observed in Fig. 4(b), very different protein profiles were obtained between lowand high-C: $N$ cultures of the four strains. Great differences were apparent in the range of low-molecularmass proteins (less then $30 \mathrm{kDa}$ ). The protein profile of FAJ0204 grown under low $\mathrm{C}: \mathrm{N}$ is similar to the profile of the other strains, including itself, obtained from high$\mathrm{C}: \mathrm{N}$ cultures. As was previously established, this strain aggregates strongly, even under low $\mathrm{C}: \mathrm{N}$ (Table 1).

It is possible that some of the differential bands from sonicated suspensions are intracellular proteins that were released during sonication. Thus, the differences observed may result from differences in the metabolism between low- and high-C: $\mathrm{N}$ conditions. However, it is still possible that one or more bands represent extracellular protein(s) involved in cell-to-cell adhesion.

Several experiments were conducted to determine whether proteolytic enzymes are able to disrupt aggregates. Trypsin and proteinase $\mathrm{K}$, at various concentrations, were not able to induce aggregate dispersion even when several rounds of homogenization were applied. However, more work is needed to elucidate the question of the possible involvement of extracellular proteins in aggregation of Azospirillum.

\section{Possible involvement of EPSs in aggregation}

Previous studies have shown that EPSs may be involved in aggregation (Sadasivan \& Neyra, 1985; Del Gallo et al., 1989; Michiels et al., 1990; Arunakumari et al., 1992; Katupitiya et al., 1995). To further investigate the possible contribution of secreted polysaccharides in aggregation, the concentration of EPS from different strains was determined. Differences in the concentration of EPS were detected between high- and low-C:N conditions and between strains (Table 1). The extent of aggregation among strains correlated with amounts of EPS in both low and high C: $\mathrm{N}$ media.

If the effect of EPS on aggregation were determined only by its concentration, it would be expected that a higher EPS concentration would be found in high $C: N$ cultures than in low $\mathrm{C}: \mathrm{N}$ ones. However, this is not the case in cultures of strains FAJ0204 and Cd (Table 1). This indicates that not only the amount of EPS produced, but also its structure and composition, may play a role in aggregation. Moreover, it was observed that in high$C: N$ EPS extracts, the ethanol-insoluble fractions precipitated and strongly adhered to the bottom of the bottle, whereas in the low $\mathrm{C}: \mathrm{N}$ extracts, ethanolinsoluble fractions tended to flutter and could be isolated only by centrifugation.

No correlation was found between aggregation and protein concentration in the growth medium. Under both low and high $C: N$, the ratio of protein to ethanol- 
insoluble EPS decreased with aggregation. These findings support the hypothesis that polysaccharides play a major role in aggregation of Azospirillum cells.

\section{Conclusions}

This work presents a consistent method enabling the study of aggregation of $A$. brasilense in high $\mathrm{C}: \mathrm{N}$ media. Fibrillar bridges were found to link cells, as observed by SEM. We are interested in investigating the nature of these adherent fibrils.

Studies on the effect of several chemical and physical factors on aggregation capacity demonstrate the high cohesiveness of aggregates formed under high $\mathrm{C}: \mathrm{N}$. Only resuspension of the culture in low concentrations of urea allowed complete disruption of aggregates, whereas reversible disaggregation occurred in heated suspensions. These findings indicate the possible involvement of hydrogen bonds, as has been observed in other bacterial and yeast systems (Calleja, 1984). Aggregation of $A$. brasilense cells is an active process, since its induction occurs under certain physiological conditions. However, when aggregates are disrupted, even by treatments that affect bacterial viability, such as exposure to heat, drastic $\mathrm{pH}$, sonication and various chemicals, aggregates are re-formed, sometimes to higher extents than in untreated controls, suggesting that the molecules involved are very stable.

The differences in EPS concentration observed by using different strains and varying $C: N$ ratios support the hypothesis that EPSs play a role in the aggregation process. With respect to the role of extracellular proteins, no sharp differences explaining the aggregating behaviour of the various strains could be detected. Clear variation was observed in extracts of high- and low$\mathrm{C}: \mathrm{N}$ grown cells after sonication, especially in their profile of relatively low-molecular-mass proteins. However, the differences in the aggregation capacity of cultures of the various strains grown at high $C: N$ were not reflected in their protein profiles. We cannot discard the possibility that the putative protein may be constitutively expressed, and in this case, aggregating behaviour could be determined by structural modifications rather than by synthesis de novo. The glycoprotein detected has a molecular mass similar to the one previously described as participating in the adherence of cells to roots (Croes et al., 1993) but is probably not involved in the aggregation process as it could not be found in FAJ0204, the 'superaggregating' strain.

Based on these findings, it is proposed that EPSs of $A$. brasilense participate in cell-to-cell adhesion during aggregation by acting as non-specific flocculants, or through interaction with proteins or other molecules attached to the bacterial envelope. Cell-surface lectins of A. brasilense and A. lipoferum have been suggested to be involved in the adhesion of these bacteria to wheat roots (Nikitina et al., 1996). In this study, differences in the extent of aggregation among the tested strains could be related to the concentration of EPS present and/or to its composition, and not to a protein constituent that may be present in all strains to the same degree. The nature of the EPS and the differentially expressed low-molecular-mass proteins obtained after sonication are now under study. A bioassay for the detection of added surface extracts from aggregating cells involved in aggregation is also being developed. This assay may help isolate and define factors directly involved in the aggregation of Azospirillum cells.

\section{ACKNOWLEDGEMENTS}

We thank J. Vanderleyden and S. Moens from the F. A. Janssens Laboratorium voor Genetica of the Katholieke Universiteit Leuven (Belgium) for the antiserum Fla1 and the Tn5 mutant FAJ0204. We also thank C. Elmerich from the Unité de Physiologie Cellulaire, Département des Biotechnologies of the Institut Pasteur (France) for the Tn5 mutant Sp72002.

\section{REFERENCES}

Arunakumari, A., Lamm, R. B. \& Neyra-Estens, C. A. (1992). Changes in cell surface properties of azospirilla in relation to cell pleomorphism and aggregation. Symbiosis 13, 291-305.

Bachhawat, A. K. \& Ghosh, S. (1987). Isolation and characterization of the outer membrane proteins of A. brasilense. J Gen Microbiol 133, 1751-1758.

Bashan, Y. \& Holguin, G. (1997). Azospirillum-plant relationships: environmental and physiological advances (1990-1996). Can J Microbiol 43, 103-121.

Bradford, M. M. (1976). A rapid and sensitive method for quantitation of microgram quantities of protein utilizing the principle of protein-dye binding. Anal Biochem 72, 248-254.

Calleja, J. B. (1984). Microbial Aggregation. Boca Raton: CRC Press.

Croes, C. L., Moens, S., Van Bastelaere, E., Vanderleyden, J. \& Michiels, K. W. (1993). The polar flagellum mediates Azospirillum brasilense adsorption to wheat roots. J Gen Microbiol 139, 2261-2269.

Daniels, S. L. (1980). Mechanisms involved in sorption of microorganisms to solid surfaces. In: Adsorption of Microorganisms to Surfaces, pp. 7-58. Edited by G. Bitton \& K. C. Marshall. NY: Wiley.

Del Gallo, M. \& Haegi, A. (1990). Characterization and quantification of exocellular polysaccharides in Azospirillum brasilense and Azospirillum lipoferum. Symbiosis 9, 155-161.

Del Gallo, M., Negi, M. \& Neyra, C. A. (1989). Calcofluor and lectin-binding exocellular polysaccharides of Azospirillum brasilense and Azospirillum lipoferum. J Bacteriol 171, 3504-3510.

De Troch, P. \& Vanderleyden, J. (1996). Surface properties and motility of Rizobium and Azospirillum in relation to plant root attachment. Microb Ecol 32, 149-169.

Dische, Z. (1962). General color reactions. Methods Carbohydr Chem 1, 477-479.

Dufrêne, Y. F. \& Rouxhet, P. C. (1996). Surface composition, surface properties, and adhesiveness of Azospirillum brasilensevariation during growth. Can J Microbiol 42, 548-556.

Dufrêne, Y. F., Boonaert, C. J. P. \& Rouxhet, P. C. (1996a). Adhesion of Azospirillum brasilense: role of proteins at the cell-support interface. Colloids Surf B: Biointerfaces 7, 113-128. 
Dufrêne, Y. F., Vermeiren, H., Vanderleyden, J. \& Rouxhet, P. C. (1996b). Direct evidence for the involvement of extracellular proteins in the adhesion of Azospirillum brasilense. Microbiology 142, 855-865.

Eggset, G., Stenberg, E. \& Kjosbakken, J. (1983). Flocculation of a Methylomonas sp. : possible involvement of a surface protein. $J$ Gen Microbiol 129, 3611-3617.

Eskew, D. L., Focht, D. D. \& Ting, I. P. (1977). Nitrogen fixation, denitrification and pleomorphic growth in highly pigmented Spirillum lipoferum. Can J Microbiol 34, 582-585.

Foster, R. C. \& Bowen, G. D. (1982). Plant surfaces and bacterial growth: the rhizosphere and rhizoplane prokaryotic pathogens and symbionts. In Phytopathogenic Prokaryotes, vol 1, pp. 159-185. Edited by M. S. Mount \& G. H. Lacy. NY: Academic Press.

Hancock, R. E. W. \& Carey, A. M. (1979). Outer membrane of Pseudomonas aeruginosa: heat and 2-mercaptoethanol-modifiable proteins. $J$ Bacteriol 140, 902-910.

Harlow, E. \& Lane, D. (1988). Antibodies: A Laboratory Manual. Cold Spring Harbor, New York : Cold Spring Harbor Laboratory.

Harris, R. H. \& Mitchell, R. (1973). Microorganisms in surface films from soil crumbs. Annu Rev Microbiol 27, 27-50.

Katupitiya, S., Millet, J., Vesk, M., Viccars, L., Zeman, A., Lidong, Z., Elmerich, C. \& Kennedy, I. R. (1995). A mutant of Azospirillum brasilense $\mathrm{Sp} 7$ impaired in flocculation with a modified colonization pattern and superior nitrogen fixation in association with wheat. Appl Environ Microbiol 61, 1987-1995.

Ma, Y., Lassiter, M. O., Banas, J. A., Galperin, M. Y., Taylor, K. G. \& Doyle, R. J. (1996). Multiple glucan-binding proteins of Streptococcus sobrinus. J Bacteriol 178, 1572-1577.

Madi, L. \& Henis, Y. (1989). Aggregation in Azospirillum brasilense $\mathrm{Cd}$ : conditions and factors involved in cell-to-cell adhesion. Plant Soil 115, 89-98.

Madi, L., Kessel, M., Sadovnik, E. \& Henis, Y. (1988). Electron microscopic studies of aggregation and pellicle formation in Azospirillum spp. Plant Soil 109, 115-121.

Marsh, P. D. \& Bradshaw, D. J. (1995). Dental plaque as a biofilm. $J$ Ind Microbiol 15, 169-175.

Marshall, K. C. (1976). Interfaces in Microbial Ecology. Cambridge, MA: Harvard University Press.

Michiels, K., Verreth, C. \& Vanderleyden, J. (1990). Azospirillum lipoferum and Azospirillum brasilense surface polysaccharide mutants that are affected in flocculation. J Appl Bacteriol 69, 705-711.

Michiels, K. W., Croes, C. L. \& Vanderleyden, J. (1991). Two different modes of attachment of Azospirillum brasilense $\mathrm{Sp} 7$ to wheat roots. J Gen Microbiol 137, 2241-2246.

Moens, S. \& Vanderleyden, J. (1996). Functions of bacterial flagella. Crit Rev Microbiol 22, 67-100.

Moens, S., Michiels, K. \& Vanderleyden, J. (1995). Glycosylation of the flagellin of the polar flagellum of Azospirillum brasilense, a Gram-negative nitrogen-fixing bacterium. Microbiology 141, 2651-2657.

Neyra, C. A., Atkinson, A. \& Olubayi, O. (1995). Coaggregation of Azospirillum with other bacteria: basis for functional diversity. NATO ASI Ser Ser G Ecol Sci 37, 429-439.

Nikitina, V. E., Alenkina, S. A., Ponomareva, E. G. \& Savenkova, N. N. (1996). Role of lectins of the cell surface of azospirilla in association with wheat roots. Mikrobiologiya 65, 165-170 (In Russian).

Nur, l., Steinitz, Y. L., Okon, Y. \& Henis, Y. (1981). Carotenoid composition and function in nitrogen-fixing bacteria of the genus Azospirillum. J Gen Microbiol 123, 27-32.

Okon, Y. \& Labandera-Gonzalez, C. A. (1994). Agronomic applications of Azospirillum. An evaluation of 20 years worldwide field inoculation. Soil Biol Biochem 26, 1591-1601.

Okon, Y., Albrecht, S. L. \& Burris, R. H. (1977). Methods for growing Spirillum lipoferum and for counting it in pure culture and in association with plants. Appl Environ Microbiol 33, 85-88.

Ramakrishnan, G., Zhao, J. L. \& Newton, A. (1994). Multiple structural proteins are required for both transcriptional activation and negative autoregulation of Caulobacter crescentus flagellar genes. J Bacteriol 176, 7587-7600.

Reniero, R., Cocconcelli, P., Bottazzi, V. \& Morelli, L. (1992). High frequency of conjugation in Lactobacillus mediated by an aggregation-promoting factor. J Gen Microbiol 138, 763-768.

Sadasivan, L. \& Neyra, C. A. (1985). Flocculation in Azospirillum brasilense and Azospirillum lipoferum: exopolysaccharides and cyst formation. J Bacteriol 163, 716-723.

Schloter, M., Moens, S., Croes, C., Reidel, G., Esquenet, M., De Mot, R., Hartmann, A. \& Michiels, K. (1994). Characterization of cell surface components of Azospirillum brasilense $\mathrm{Sp} 7$ as antigenic determinants for strain-specific monoclonal antibodies. Microbiology 140, 823-828.

Tarrand, J. J., Krieg, N. R. \& Dobereiner, J. (1978). A taxonomic study of the Spirillum lipoferum group with the description of a new genus, Azospirillum gen. nov. and two species, Azospirillum lipoferum (Beijerinck) comb. nov. and Azospirillum brasilense sp. nov. Can J Microbiol 24, 967-980.

Wai, S. N., Takade, A. \& Amako, K. (1996). The hydrophobic surface protein layer of enteroaggregative Escherichia coli strains. FEMS Microbiol Lett 135, 17-22.

Wang, H., Broadbent, J. R. \& Kondo, J. K. (1994). Analysis of the physical and functional characteristics of cell clumping in lactosepositive transconjugants of Lactococcus lactis ssp. lactis ML3.J Dairy Sci 77, 375-384.

Wood, P. J. \& Fulcher, R. G. (1978). Interaction of some dyes with cereal $\beta$-glucans. Cereal Chem 55, 952-966.

Received 3 November 1997; revised 16 March 1998; accepted 18 March 1998. 